\title{
Cerebral Blood Flow in Coarctation of the Aorta
}

\author{
George G. Rowe, Cesar A. Castillo, Skoda Afonso, William P. Young, and \\ Charles W. Crum pton \\ (From the Cardiovascular Research Laboratory, Departments of Medicine and Surgery, \\ University of Wisconsin Medical School, Madison, Wis.)
}

The hemodynamics of coarctation of the aorta have been extensively investigated. These studies have shown that the renal blood flow is within normal limits (1), as in flow to the extremities (2$4)$, even though the circulation time to the lower parts of the body has a tendency to be prolonged (5). Although coronary blood flow has been reported to be increased (6), the data are quite scattered, and if the two youngest subjects (12 and 15 years old) were excluded, the results would be within normal limits. Left ventricular oxygen consumption was increased in all subjects in the series regardless of age or rate of coronary flow (6). Cardiac output is reported as increased (7) or normal (6) by both the Fick principle and the acetylene method (5). No sizable series has been reported in which cerebral blood flow has been measured, although in two subjects it was reported to be increased (8). Since the cerebral circulation is in the portion of the body where the mean arterial blood pressure is elevated, it appeared worthwhile to study a larger group of subjects to see whether the cerebral vascular resistance adapted itself to this increase in pressure or whether the reported increase in cerebral blood flow (8) was consistent in a larger group. Furthermore, information concerning the relation of the rate of blood perfusion to oxygen consumption is needed for the brain, since it is reported that under certain conditions when coronary blood flow is increased through mechanical means in the isolated or partially isolated preparation, the myocardial oxygen consumption is also increased (913). Hence under certain conditions that are apparently unrelated to hypoxia, coronary blood flow

\footnotetext{
* Submitted for publication April 2, 1964; accepted June 18, 1964. This study was supported in part by grants from the National Heart Institute, U. S. Public Health Service, the Wisconsin Heart Association, and the Wisconsin Alumni Research Foundation.
}

may control myocardial oxygen consumption (911).

\section{Methods}

Cerebral blood flow was determined by the nitrous oxide saturation method (14) in 20 subjects with coarctation of the aorta. The possibility was considered that there might be a significant delay in the passage of blood through the collateral channels about the coarcted segment of the aorta to the femoral artery (5), and, as a result, the femoral arterial nitrous oxide curve might be shifted to the right. If this were true, the femoral arterial versus internal jugular nitrous oxide curves as compared to the brachial arterial versus internal jugular curves would reveal factitial narrowing of the arteriovenous nitrous oxide difference and result in a calculated increase in the cerebral blood flow, as estimated from the femoral artery site. Therefore 11 subjects with coarctation of the aorta were studied by simultaneous measurement of the cerebral blood flow with both the femoral and brachial arterial blood samples. The technique was a very simple modification of the usual method for determining cerebral blood flow in that needles were placed in both the femoral and the brachial arteries as well as in the internal jugular bulb. Specimens were then drawn simultaneously from all three sites. Nitrous oxide analyses were performed, and two sets of curves were drawn. The cerebral blood flow was calculated in the usual manner by utilizing both the femoral arterial-internal jugular venous nitrous oxide difference as well as the brachial arterial-internal jugular nitrous oxide difference. In two subjects similar simultaneous brachial, femoral, and internal jugular sampling was performed postoperatively.

In 16 subjects cerebral blood flow and cerebral oxygen and carbon dioxide metabolism were determined before and after surgical correction of the coarctation of the aorta. Postoperative studies were done in all cases after the patient had recovered sufficiently from the surgical procedure to be comfortable during the measurement of cerebral blood flow. The time interval between studies varied between 15 days and 9.25 years, and for the overall series averaged 21 months.

The data were analyzed by the $t$ test, comparing first the simultaneous determination of cerebral flow as meassured utilizing the femoral arterial versus the internal jugular nitrous oxide curves with that as determined by utilizing the brachial arterial versus internal jugular ni- 
trous oxide curve. The preoperative and postoperative data for each subject were also compared, each subject serving as his own control. Finally, the entire group of 20 subjects was compared with a series of subjects with arterial hypertension (15) and a group of normal subjects studied previously in this laboratory (16) and with the group of normals reported by Kety and Schmidt (14).

\section{Results}

In all 17 subjects in whom the femoral arterial mean pressure could be compared with brachial arterial mean pressure a significant difference was demonstrated from above to below the coarctation. These data are presented, as has been done in the past (17-19), to give information as to the severity of the coarctation.

Further results are presented in the tables. Table I reveals a comparison of cerebral blood flow as measured from the nitrous oxide curves obtained by sampling simultaneously from the brachial artery, femoral artery, and internal jugular bulb. Since there was no significant difference between the values obtained, we concluded that for the rest of the study these data could be used interchangeably. The data for the entire group of 20 were pooled in Table II without particular reference as to whether the cerebral blood flow had been determined by utilizing the brachial or femoral site for arterial specimens. Thus the figures included are the average of the brachial and femoral if both studies were done simultaneously (13 studies), the brachial if that alone was done (14 studies), or the femoral if that alone was done (9 studies). Sixteen subjects had determination of cerebral blood flow before and after surgical correction of coarctation of the aorta. As indicated in Table II no significant difference was demonstrated between preoperative and postoperative cerebral blood flow, vascular resistance, or oxygen utilization.

The present results in subjects with coarctation were compared with the results in a series of normal subjects previously reported (16) by utilizing the $t$ test for unpaired groups of data. The cerebral oxygen consumption was $20 \%$ greater in those with coarctation $(\mathrm{p}<0.02)$. The mean brachial arterial blood pressure was significantly higher than in the normals $(p<0.001)$, and the cerebral vascular resistance was significantly greater $(+16.2 \%, \mathrm{p}<0.02)$. When compared
TABLE I

\begin{tabular}{|c|c|c|c|c|}
\hline \multirow[b]{2}{*}{ Subject no. } & \multicolumn{2}{|c|}{ Cerebral blood flow } & \multicolumn{2}{|c|}{$\begin{array}{l}\text { Cerebral metabolic } \\
\text { rate for } \mathrm{O}_{2}\end{array}$} \\
\hline & BA-IJ & FA-IJ & BA-IJ & FA-IJ \\
\hline & \multicolumn{2}{|c|}{$\mathrm{ml} / 100 \mathrm{~g} / \mathrm{min}$} & \multicolumn{2}{|c|}{$\mathrm{ml} / 100 \mathrm{~g} / \mathrm{min}$} \\
\hline $\begin{array}{r}1 \\
2 \\
3 \\
4 \\
5 \\
6 \\
7 \\
8 \\
9 \\
10 \\
11\end{array}$ & $\begin{array}{l}60 \\
83 \\
56 \\
62 \\
48 \\
60 \\
46 \\
74 \\
56 \\
67 \\
49\end{array}$ & $\begin{array}{l}61 \\
90 \\
67 \\
64 \\
43 \\
62 \\
48 \\
74 \\
56 \\
68 \\
52\end{array}$ & $\begin{array}{l}4.0 \\
5.3 \\
3.9 \\
3.3 \\
3.8 \\
3.7 \\
2.4 \\
5.0 \\
3.4 \\
3.7 \\
3.5\end{array}$ & $\begin{array}{l}4.1 \\
5.8 \\
4.4 \\
3.5 \\
3.4 \\
3.8 \\
2.5 \\
5.0 \\
3.4 \\
3.7 \\
3.7\end{array}$ \\
\hline Average $\pm S D$ & $\begin{array}{r}60 \pm 11 \\
p\end{array}$ & $.2 \pm 13$ & $\begin{array}{r}3.8 \pm 0.8 \\
p\end{array}$ & $3.9 \pm 0.9$ \\
\hline
\end{tabular}

* BA-IJ refers to cerebral blood flow as calculated by utilizing the nitrous oxide difference between the brachial arterial and internal jugular blood, whereas FA-IJ refers to similar calculations utilizing the femoral arterial-internal jugular blood nitrous oxide difference.

with the previous series of normals studied in this laboratory (15), the brachial arterial blood pressure in subjects with coarctation was elevated ( $p<0.01$ ), as was cerebral oxygen consumption $(+17.5 \%, p<0.05)$. The cerebral vascular resistance in our group of normal subjects was sufficiently higher than in the preceding group (14), and it did not differ from those with coarctation of the aorta. Since coarctation of the aorta is commonly recognized as a cause of hypertension, comparisons were also made between a group of hypertensive subjects studied in this laboratory (15) and the present group with coarctation of the aorta. There were no significant differences in the cerebral blood flow or cerebral oxygen consumption. The mean arterial blood pressure and cerebral vascular resistance in the coarctation group were significantly less than those observed in the subjects with severe hypertension (15).

\section{Discussion}

The general hemodynamic parameters of coarctation are sufficiently well known that they do not require further discussion. The preoperative and postoperative differences between the femoral and the brachial pressure have been reported in detail previously $(18,19)$ and are included in this paper only as an indication of the severity of the lesion and as evidence that surgical correction of the coarctation was adequate. This 
TABLE II

Data concerning cerebral blood

\begin{tabular}{|c|c|c|c|c|c|c|c|}
\hline \multirow[b]{2}{*}{ Subject } & \multirow[b]{2}{*}{ Status } & \multirow[b]{2}{*}{$\begin{array}{l}\text { Date of } \\
\text { study }\end{array}$} & \multirow[b]{2}{*}{ Sex } & \multirow[b]{2}{*}{ Age } & \multicolumn{2}{|c|}{ Mean blood pressure } & \multirow[b]{2}{*}{$\underset{\text { content }}{\text { Arterial } \mathrm{O}_{2}}$} \\
\hline & & & & & $\begin{array}{l}\text { Brachial } \\
\text { arterial }\end{array}$ & $\begin{array}{c}\text { Femoral } \\
\text { arterial }\end{array}$ & \\
\hline & & & & $y r s$ & \multicolumn{2}{|c|}{$m m \mathrm{Hg}$} & $\mathrm{ml} / 100 \mathrm{ml}$ of blood \\
\hline M.B. & $\begin{array}{l}\mathrm{B}^{*} \\
\mathrm{~A}\end{array}$ & $\begin{array}{l}11 / 24 / 59 \\
12 / 10 / 62\end{array}$ & $\mathbf{M}$ & $\begin{array}{l}15.00 \\
18.04\end{array}$ & $\begin{array}{r}89 \\
114\end{array}$ & $\begin{array}{r}69 \\
119\end{array}$ & $\begin{array}{l}16.7 \\
17.4\end{array}$ \\
\hline R.W. & $\begin{array}{l}\text { B } \\
\text { A }\end{array}$ & $\begin{array}{r}8 / 29 / 52 \\
11 / 10 / 52\end{array}$ & M & $\begin{array}{l}16.75 \\
16.95\end{array}$ & 115 & $\begin{array}{l}103 \\
118\end{array}$ & $\begin{array}{l}20.7 \\
15.6\end{array}$ \\
\hline L.H. & $\begin{array}{l}\text { B } \\
\text { A }\end{array}$ & $\begin{array}{l}12 / 27 / 60 \\
12 / 3 / 62\end{array}$ & M & $\begin{array}{l}17.00 \\
18.93\end{array}$ & $\begin{array}{l}125 \\
118\end{array}$ & $\begin{array}{l}100 \\
115\end{array}$ & $\begin{array}{l}18.9 \\
19.4\end{array}$ \\
\hline C.B. & $\begin{array}{l}\text { B } \\
\text { A }\end{array}$ & $\begin{array}{r}6 / 3 / 53 \\
10 / 6 / 62\end{array}$ & $\mathrm{~F}$ & $\begin{array}{l}17.33 \\
26.67\end{array}$ & $\begin{array}{r}138 \\
98\end{array}$ & $\begin{array}{l}110 \\
102\end{array}$ & $\begin{array}{l}16.2 \\
15.9\end{array}$ \\
\hline W.G. & $\begin{array}{l}\text { B } \\
\text { A }\end{array}$ & $\begin{array}{r}6 / 14 / 56 \\
11 / 12 / 62\end{array}$ & M & $\begin{array}{l}17.50 \\
23.83\end{array}$ & $\begin{array}{l}105 \\
114\end{array}$ & $\begin{array}{r}87 \\
106\end{array}$ & $\begin{array}{l}18.3 \\
17.9\end{array}$ \\
\hline D.L. & $\begin{array}{l}\text { B } \\
\text { A }\end{array}$ & $\begin{array}{l}8 / 14 / 56 \\
8 / 30 / 56\end{array}$ & $\mathbf{M}$ & $\begin{array}{l}17.75 \\
17.79\end{array}$ & $\begin{array}{l}89 \\
96\end{array}$ & $\begin{array}{l}81 \\
97\end{array}$ & $\begin{array}{l}18.2 \\
16.5\end{array}$ \\
\hline W.L. & $\begin{array}{l}\text { B } \\
\text { A }\end{array}$ & $\begin{array}{l}9 / 4 / 52 \\
9 / 19 / 52\end{array}$ & M & $\begin{array}{l}19.83 \\
19.87\end{array}$ & $\begin{array}{l}153 \\
117\end{array}$ & $\begin{array}{l}105 \\
101\end{array}$ & $\begin{array}{l}22.2 \\
16.2\end{array}$ \\
\hline W.J. & $\begin{array}{l}\text { B } \\
\text { A }\end{array}$ & $\begin{array}{r}2 / 3 / 61 \\
12 / 17 / 62\end{array}$ & M & $\begin{array}{l}21.00 \\
22.87\end{array}$ & $\begin{array}{l}135 \\
119\end{array}$ & $\begin{array}{l}104 \\
116\end{array}$ & $\begin{array}{l}19.4 \\
19.4\end{array}$ \\
\hline R.B. & $\begin{array}{l}\text { B } \\
\text { A }\end{array}$ & $\begin{array}{r}9 / 24 / 53 \\
10 / 12 / 53\end{array}$ & M & $\begin{array}{l}21.25 \\
21.30\end{array}$ & $\begin{array}{l}129 \\
101\end{array}$ & $\begin{array}{r}116 \\
99\end{array}$ & $\begin{array}{l}19.7 \\
15.9\end{array}$ \\
\hline K.V. & $\begin{array}{l}\mathrm{B} \\
\mathrm{A}\end{array}$ & $\begin{array}{l}11 / 30 / 60 \\
10 / 19 / 62\end{array}$ & M & $\begin{array}{l}22.00 \\
23.88\end{array}$ & $\begin{array}{l}98 \\
99\end{array}$ & $\begin{array}{l}91 \\
97\end{array}$ & $\begin{array}{l}19.2 \\
18.5\end{array}$ \\
\hline C.H. & $\begin{array}{l}\text { B } \\
\text { A }\end{array}$ & $\begin{array}{l}8 / 21 / 56 \\
9 / 12 / 56\end{array}$ & M & $\begin{array}{l}27.50 \\
27.56\end{array}$ & $\begin{array}{r}114 \\
92\end{array}$ & $\begin{array}{l}98 \\
86\end{array}$ & $\begin{array}{l}21.2 \\
13.0\end{array}$ \\
\hline M.W. & B & $2 / 14 / 61$ & $\mathrm{~F}$ & 29.00 & 120 & 89 & 17.4 \\
\hline H.S. & $\begin{array}{l}\text { B } \\
\text { A }\end{array}$ & $\begin{array}{l}7 / 7 / 52 \\
7 / 25 / 52\end{array}$ & M & $\begin{array}{l}30.00 \\
30.05\end{array}$ & $\begin{array}{l}120 \\
103\end{array}$ & 86 & $\begin{array}{l}20.0 \\
16.9\end{array}$ \\
\hline H.G. & $\begin{array}{l}\mathrm{B} \\
\mathrm{A}\end{array}$ & $\begin{array}{l}6 / 11 / 52 \\
2 / 17 / 53\end{array}$ & M & $\begin{array}{l}31.00 \\
31.69\end{array}$ & $\begin{array}{r}136 \\
90\end{array}$ & 65 & $\begin{array}{l}19.7 \\
21.1\end{array}$ \\
\hline W.Mc. & $\begin{array}{l}\text { B } \\
\text { A }\end{array}$ & $\begin{array}{r}12 / 9 / 53 \\
8 / 24 / 54\end{array}$ & M & $\begin{array}{l}31.80 \\
32.50\end{array}$ & $\begin{array}{r}112 \\
97\end{array}$ & 85 & $\begin{array}{l}19.9 \\
20.9\end{array}$ \\
\hline J.E. & B & $1 / 23 / 53$ & M & 36.00 & 101 & 80 & 15.9 \\
\hline C.E. & B & $11 / 17 / 53$ & M & 42.00 & 113 & & 20.0 \\
\hline D.S. & $\begin{array}{l}\text { B } \\
\text { A }\end{array}$ & $\begin{array}{r}11 / 15 / 60 \\
1 / 14 / 63\end{array}$ & $\mathrm{~F}$ & $\begin{array}{l}42.00 \\
44.20\end{array}$ & $\begin{array}{l}116 \\
105\end{array}$ & $\begin{array}{l}93 \\
99\end{array}$ & $\begin{array}{l}17.9 \\
18.3\end{array}$ \\
\hline E.E. & B & $5 / 28 / 53$ & $\mathrm{~F}$ & 44.50 & 105 & 75 & 17.6 \\
\hline D.W. & $\begin{array}{l}\text { B } \\
\text { A }\end{array}$ & $\begin{array}{r}7 / 16 / 62 \\
11 / 19 / 62\end{array}$ & $\mathrm{~F}$ & $\begin{array}{l}46.00 \\
46.34\end{array}$ & $\begin{array}{r}102 \\
93\end{array}$ & $\begin{array}{l}75 \\
91\end{array}$ & $\begin{array}{l}19.0 \\
15.9\end{array}$ \\
\hline $\begin{array}{l}16 \text { cases } \\
\text { Average } \pm \mathrm{SD} \\
\% \text { change } \\
\text { p value }\end{array}$ & $\begin{array}{l}\text { B } \\
\text { A }\end{array}$ & & & & $\begin{array}{c}116 \pm 20 \dagger \\
106 \pm 10 \dagger \\
-10 \\
<0.1\end{array}$ & $\begin{array}{c}94 \pm 14 \dagger \\
102 \pm 10 \dagger \\
+8.5 \\
<0.1\end{array}$ & $\begin{array}{c}19.2 \pm 1.5 \\
17.4 \pm 2.1 \\
-9.4 \\
<0.05\end{array}$ \\
\hline $\begin{array}{l}20 \text { cases } \\
\text { Average } \pm S D\end{array}$ & B & & & $27.3 \pm 10.3$ & $116 \pm 17$ & $93 \pm 13$ & $18.9 \pm 1.6$ \\
\hline
\end{tabular}

${ }^{*} \mathrm{~B}=$ before and $\mathrm{A}=$ after surgical correction of the coarctation of the aorta.

$\dagger$ In those cases where both figures are available pre- and postoperativelv. 
TABLE II

flow in coarctation of the aorta*

\begin{tabular}{|c|c|c|c|c|c|c|c|}
\hline $\begin{array}{l}\text { Arterial-in- } \\
\text { ternal jugular } \\
\mathrm{O}_{2} \text { difference }\end{array}$ & $\begin{array}{c}\text { Internal } \\
\text { jugular } \\
\mathrm{CO}_{2} \text { content }\end{array}$ & Cerebral RQ & $\begin{array}{c}\text { Cerebral } \\
\text { blood flow }\end{array}$ & $\begin{array}{l}\text { Cerebral } \\
\text { metabolic } \\
\text { rate for } \mathrm{O}_{2}\end{array}$ & $\begin{array}{l}\text { Cerebral vascu- } \\
\text { lar resistance }\end{array}$ & Hemoglobin & $\underset{\text { rate }}{\text { Heart }}$ \\
\hline \multicolumn{2}{|c|}{$\mathrm{ml} / 100 \mathrm{ml}$ of blood } & & \multicolumn{2}{|c|}{$\mathrm{ml} / 100 \mathrm{~g} / \min$} & $U$ & $\mathrm{~g} / 100 \mathrm{ml}$ & \\
\hline $\begin{array}{l}6.7 \\
4.8\end{array}$ & $\begin{array}{l}47.0 \\
47.4\end{array}$ & $\begin{array}{l}0.91 \\
1.00\end{array}$ & $\begin{array}{l}61 \\
68\end{array}$ & $\begin{array}{l}4.1 \\
3.3\end{array}$ & $\begin{array}{l}1.46 \\
1.68\end{array}$ & $\begin{array}{l}12.8 \\
14.3\end{array}$ & $\begin{array}{r}94 \\
114\end{array}$ \\
\hline $\begin{array}{l}6.2 \\
5.9\end{array}$ & $\begin{array}{l}53.6 \\
57.5\end{array}$ & $\begin{array}{l}0.87 \\
0.97\end{array}$ & $\begin{array}{l}63 \\
58\end{array}$ & $\begin{array}{l}3.9 \\
3.4\end{array}$ & 1.83 & $\begin{array}{l}16.1 \\
11.3\end{array}$ & 90 \\
\hline $\begin{array}{l}6.8 \\
7.2\end{array}$ & $\begin{array}{l}50.7 \\
51.8\end{array}$ & $\begin{array}{l}0.90 \\
0.90\end{array}$ & $\begin{array}{l}74 \\
60\end{array}$ & $\begin{array}{l}5.0 \\
4.3\end{array}$ & $\begin{array}{l}1.69 \\
1.97\end{array}$ & 14.4 & $\begin{array}{l}84 \\
82\end{array}$ \\
\hline $\begin{array}{l}5.8 \\
4.5\end{array}$ & $\begin{array}{l}50.5 \\
45.5\end{array}$ & $\begin{array}{l}0.86 \\
1.00\end{array}$ & $\begin{array}{l}94 \\
71\end{array}$ & $\begin{array}{l}5.5 \\
3.2\end{array}$ & $\begin{array}{l}1.47 \\
1.38\end{array}$ & $\begin{array}{l}11.6 \\
13.2\end{array}$ & $\begin{array}{l}77 \\
80\end{array}$ \\
\hline $\begin{array}{l}6.6 \\
3.3\end{array}$ & $\begin{array}{l}56.8 \\
51.4\end{array}$ & $\begin{array}{l}0.88 \\
1.15\end{array}$ & $\begin{array}{l}63 \\
41\end{array}$ & $\begin{array}{l}4.2 \\
1.4\end{array}$ & $\begin{array}{l}1.67 \\
2.78\end{array}$ & $\begin{array}{l}14.4 \\
14.4\end{array}$ & $\begin{array}{l}67 \\
72\end{array}$ \\
\hline $\begin{array}{l}5.4 \\
5.5\end{array}$ & $\begin{array}{l}54.2 \\
56.9\end{array}$ & $\begin{array}{l}0.98 \\
0.97\end{array}$ & $\begin{array}{l}63 \\
53\end{array}$ & $\begin{array}{l}3.4 \\
2.9\end{array}$ & $\begin{array}{l}1.41 \\
1.81\end{array}$ & $\begin{array}{l}11.6 \\
14.1\end{array}$ & $\begin{array}{l}80 \\
92\end{array}$ \\
\hline $\begin{array}{l}6.4 \\
6.0\end{array}$ & $\begin{array}{l}50.4 \\
57.1\end{array}$ & $\begin{array}{l}0.91 \\
0.92\end{array}$ & $\begin{array}{l}87 \\
68\end{array}$ & $\begin{array}{l}5.6 \\
4.1\end{array}$ & $\begin{array}{l}1.75 \\
1.72\end{array}$ & $\begin{array}{l}17.6 \\
12.7\end{array}$ & 83 \\
\hline $\begin{array}{l}6.1 \\
6.1\end{array}$ & $\begin{array}{l}53.2 \\
50.7\end{array}$ & $\begin{array}{l}0.89 \\
1.00\end{array}$ & $\begin{array}{l}56 \\
50\end{array}$ & $\begin{array}{l}3.4 \\
3.1\end{array}$ & $\begin{array}{l}2.41 \\
2.38\end{array}$ & $\begin{array}{l}15.0 \\
15.1\end{array}$ & $\begin{array}{l}114 \\
111\end{array}$ \\
\hline $\begin{array}{l}6.1 \\
5.3\end{array}$ & $\begin{array}{l}54.5 \\
58.4\end{array}$ & $\begin{array}{l}0.82 \\
0.91\end{array}$ & $\begin{array}{l}67 \\
72\end{array}$ & $\begin{array}{l}4.1 \\
3.8\end{array}$ & $\begin{array}{l}1.93 \\
1.40\end{array}$ & $\begin{array}{l}16.4 \\
13.1\end{array}$ & $\begin{array}{l}81 \\
87\end{array}$ \\
\hline $\begin{array}{l}5.2 \\
5.5\end{array}$ & $\begin{array}{l}52.1 \\
52.6\end{array}$ & $\begin{array}{l}0.87 \\
0.98\end{array}$ & $\begin{array}{l}47 \\
81\end{array}$ & $\begin{array}{l}2.4 \\
4.5\end{array}$ & $\begin{array}{l}2.09 \\
1.22\end{array}$ & $\begin{array}{l}15.4 \\
14.0\end{array}$ & $\begin{array}{l}85 \\
71\end{array}$ \\
\hline $\begin{array}{l}8.0 \\
5.4\end{array}$ & $\begin{array}{l}57.4 \\
58.1\end{array}$ & $\begin{array}{l}1.00 \\
0.93\end{array}$ & $\begin{array}{l}46 \\
51\end{array}$ & $\begin{array}{l}3.7 \\
2.8\end{array}$ & $\begin{array}{l}2.48 \\
1.80\end{array}$ & $\begin{array}{l}17.4 \\
11.1\end{array}$ & $\begin{array}{r}81 \\
112\end{array}$ \\
\hline 5.5 & 51.3 & 0.89 & 68 & 3.7 & 1.76 & 13.3 & 120 \\
\hline $\begin{array}{l}6.7 \\
7.6\end{array}$ & $\begin{array}{l}55.3 \\
56.8\end{array}$ & $\begin{array}{l}0.93 \\
0.88\end{array}$ & $\begin{array}{l}73 \\
42\end{array}$ & $\begin{array}{l}4.9 \\
3.2\end{array}$ & $\begin{array}{l}1.64 \\
2.45\end{array}$ & $\begin{array}{l}15.6 \\
13.5\end{array}$ & \\
\hline $\begin{array}{l}7.1 \\
7.1\end{array}$ & $\begin{array}{l}54.2 \\
56.3\end{array}$ & $\begin{array}{l}0.85 \\
0.87\end{array}$ & $\begin{array}{l}50 \\
40\end{array}$ & $\begin{array}{l}3.6 \\
2.8\end{array}$ & $\begin{array}{l}2.72 \\
2.25\end{array}$ & $\begin{array}{l}16.2 \\
16.4\end{array}$ & $\begin{array}{l}64 \\
72\end{array}$ \\
\hline $\begin{array}{r}8.8 \\
10.6\end{array}$ & $\begin{array}{l}52.8 \\
51.7\end{array}$ & $\begin{array}{l}1.01 \\
0.94\end{array}$ & $\begin{array}{l}49 \\
67\end{array}$ & $\begin{array}{l}4.3 \\
7.1\end{array}$ & $\begin{array}{l}2.29 \\
1.45\end{array}$ & $\begin{array}{l}15.2 \\
15.2\end{array}$ & $\begin{array}{l}67 \\
74\end{array}$ \\
\hline 4.9 & 51.1 & 0.80 & 60 & 2.9 & 1.68 & 12.1 & 66 \\
\hline 5.8 & 54.2 & 0.93 & 71 & 4.1 & 1.59 & 14.8 & 56 \\
\hline $\begin{array}{l}6.1 \\
5.4\end{array}$ & $\begin{array}{l}55.1 \\
53.3\end{array}$ & $\begin{array}{l}1.05 \\
0.91\end{array}$ & $\begin{array}{l}61 \\
73\end{array}$ & $\begin{array}{l}3.7 \\
3.9\end{array}$ & $\begin{array}{l}1.90 \\
1.44\end{array}$ & $\begin{array}{l}13.8 \\
13.7\end{array}$ & $\begin{array}{l}84 \\
80\end{array}$ \\
\hline 10.5 & 43.3 & 0.86 & 46 & 4.8 & 2.28 & 13.2 & 60 \\
\hline $\begin{array}{l}7.2 \\
6.2\end{array}$ & $\begin{array}{l}57.8 \\
51.0\end{array}$ & $\begin{array}{l}0.88 \\
0.81\end{array}$ & $\begin{array}{l}51 \\
38\end{array}$ & $\begin{array}{l}3.7 \\
2.4\end{array}$ & $\begin{array}{l}2.00 \\
2.45\end{array}$ & $\begin{array}{l}14.6 \\
11.9\end{array}$ & $\begin{array}{l}65 \\
66\end{array}$ \\
\hline $\begin{array}{c}6.6 \pm 0.9 \\
6.0 \pm 1.6 \\
-9.1 \\
<0.1\end{array}$ & $\begin{array}{c}53.5 \pm 2.9 \\
53.5 \pm 3.9 \\
0 \\
0\end{array}$ & $\begin{array}{l}0.91 \pm .06 \\
0.95 \pm .08 \\
+4.4 \\
<0.3\end{array}$ & $\begin{array}{c}63 \pm 14 \\
58 \pm 14 \\
-7.9 \\
<0.1\end{array}$ & $\begin{array}{c}4.1 \pm .8 \\
3.5 \pm 1.2 \\
-14.6 \\
<0.2\end{array}$ & $\begin{array}{l}1.93 \pm .40 \\
1.88 \pm .48 \\
-2.6 \\
<0.8\end{array}$ & $\begin{array}{l}14.9 \pm 1.8 \\
13.6 \pm 1.5 \\
\quad-8.7 \\
<0.1\end{array}$ & $\begin{array}{c}80 \pm 14 \\
86 \pm 17 \\
+7.5 \\
<0.2\end{array}$ \\
\hline $6.6 \pm 1.3$ & $52.8 \pm 3.5$ & $0.90 \pm .06$ & $63 \pm 13$ & $4.0 \pm 0.8$ & $1.90 \pm .37$ & $14.6 \pm 1.8$ & $80 \pm 17$ \\
\hline
\end{tabular}


appears to be the case even though a significant residual difference $(4 \mathrm{~mm} \mathrm{Hg}$ ) was noted between the upper and the lower extremities in the postoperative measurements. It is unusual to demonstrate a difference of $4 \mathrm{~mm} \mathrm{Hg}$ between the simultaneous directly recorded brachial and femoral mean arterial pressures in the absence of some mechanical cause. Since the surgical technique for correction of coarctation of the aorta at this institution included a " $Z$ plasty" construction of the suture line, the aorta at the site of the coarctation is usually reconstructed to the same size as the aorta above the former site of coarctation. Thus it appears unlikely that significant residual constriction of the lumen remains. A similar gradient has previously been reported to persist after surgical correction of coarctation of the aorta (18). The pressure differences may be related to residual dilatation and altered elasticity of the brachio-cephalic vessels proximal to and around the coarctation site. The sustained postoperative persistence of rib notching in most but not all cases (18) may lend some support to the idea that the dilated collateral channels usually remain enlarged.

The collateral circulation about coarctation of the aorta is so efficient that nitrous oxide is delivered to the femoral artery almost as quickly as it is to the brachial. This is revealed by the fact that cerebral blood flow as calculated from the brachial arterial-internal jugular venous difference gives a result very similar to that calculated from the femoral arterial-internal jugular venous difference. Probably, if a sufficient number of subjects were studied, eventually a statistically significant difference might emerge between curves constructed by analysis of blood from these two arterial sites, since 8 of the 11 subjects in this series did demonstrate a small difference. However, there was sufficient scatter that statistical testing indicated no significant change. The scatter is probably related, among other things, to errors in the method as well as variation in the severity of the coarctation and the development of collateral circulation. The fact that lower extremity blood flow (2-4) as well as renal blood flow (1) has been found to be within normal limits in subjects with coarctation of the aorta confirms the present observation that blood is de- livered rapidly and effectively to the body below the site of the constriction.

The cerebral blood flow in subjects with coarctation of the aorta was previously reported to be higher than in normal subjects (8). It would be expected that with a group of 20 subjects, a biologically significant increase in cerebral blood flow should be apparent in statistical testing, but this was not established in the present study. Furthermore, statistical testing indicated no significant difference in cerebral blood flow before and after surgical correction.

Cerebral oxygen consumption in the group of subjects with coarctation of the aorta is increased per unit weight of brain tissue as compared to both previous series of normal subjects $(14,16)$ but is not significantly different from that in the previous series of subjects with arterial hypertension (15). The significance of this observation is not known. It is known, however, that cerebral oxygen consumption is not changed by inhalation of oxygen at 1.0 to 3.5 atmospheres (20) or by altering cerebral blood flow through administering 5 to $7 \%$ carbon dioxide, $10 \%$ oxygen, or 85 to $100 \%$ oxygen (21). There is a possibility that there is abnormal distribution of cranial blood flow in these subjects and that the increased oxygen consumption reported here is attributable to some tissue other than the brain. We have no evidence on this point. Available data indicate that if the rate of perfusion of blood through the coronary circuit is increased artificially, the myocardial oxygen consumption may be increased (9-13). The mechanism of this increase in myocardial oxygen consumption dependent upon increased blood flow is not known, and the relation, if any, to the present discussion is not clear.

\section{Summary}

1) Cerebral blood flow has been measured by the nitrous oxide method in a group of 20 subjects with coarctation of the aorta, and their cerebral oxygen consumption has been calculated.

2) In 11 of these subjects cerebral blood flow was determined by utilizing simultaneous sampling of blood from the brachial and femoral arteries as well as the internal jugular bulb. Calculations of cerebral blood flow from the two sets of curves showed no significant difference. 
3) In subjects with coarctation of the aorta the calculated cerebral oxygen consumption was increased, but their cerebral blood flow was not significantly different from normal.

4) In 16 subjects, preoperative and postoperative determinations of cerebral hemodynamics were made. These revealed that the pressure differential from the brachial to the femoral artery was largely corrected but that cerebral blood flow and vascular resistance did not change significantly.

\section{References}

1. Kirkendall, W. M., J. W. Culbertson, and J. W. Eckstein. Renal hemodynamics in patients with coarctation of the aorta. J. Lab. clin. Med. 1959, $53,6$.

2. Lewis, T. Material relating to coarctation of the aorta of the adult type. Heart 1933, 16, 205.

3. Pickering, G. W. The peripheral resistance in persistent arterial hypertension. Clin. Sci. 1935-36, 2, 209.

4. Patterson, G. C., J. T. Shepherd, and R. F. Whelan. The resistance to blood flow in the upper and lower limb vessels in patients with coarctation of the aorta. Clin. Sci. 1957, 16, 627.

5. Stewart, H. J., and R. L. Bailey, Jr. The cardiac output and other measurements of the circulation in coarctation of the aorta. J. clin. Invest. 1941, $20,145$.

6. Bing, R. J., M. M. Hammond, J. C. Handelsman, S. R. Powers, F. C. Spencer, J. E. Eckenhoff, W. T. Goodale, J. H. Hafkenschiel, and S. S. Kety. The measurement of coronary blood flow, oxygen consumption, and efficiency of the left ventricle in man. Amer. Heart. J. 1949, 38, 1.

7. Taylor, S. H., and K. W. Donald. Circulatory studies at rest and during exercise in coarctation of the aorta before and after operation. Brit. Heart J. 1960, 22, 117.

8. Hafkenschiel, J. H., Jr., C. W. Crumpton, and J. H. Moyer. Blood flow and oxygen consumption of the brain in coarctation of the aorta. Proc. Soc. exp. Biol. (N. Y.) 1949, 71, 165.

9. Gregg, D. E. Regulation of the collateral and coronary circulation of the heart in Circulat. Proc. Harvey Tercentenary Congress. Oxford, Blackwell Scientific Publications, 1958, p. 163.
10. Gregg, D. E. Effect of coronary perfusion pressure or coronary flow on oxygen usage of the myocardium. Circulat. Res. 1963, 13, 497.

11. Kahler, R. L., E. Braunwald, L. L. Kelminson, L. Kedes, C. A. Chidsey, and S. Segal. Effect of alterations of coronary blood flow on the oxygen consumption of the nonworking heart. Circulat. Res. 1963, 13, 501.

12. Sarnoff, S. J., J. P. Gilmore, N. S. Skinner, Jr., A. G. Wallace, and J. H. Mitchell. Relation between coronary blood flow and myocardial oxygen consumption. Circulat. Res. 1963, 13, 514.

13. Weisberg, H., L. N. Katz, and E. Boyd. Influence of coronary flow upon oxygen consumption and cardiac performance. Circulat. Res. 1963, 13, 522.

14. Kety, S. S., and C. F. Schmidt. The nitrous oxide method for the quantitative determination of cerebral blood flow in man: theory, procedure and normal values. J. clin. Invest. 1948, 27, 476.

15. Crumpton, C. W., G. G. Rowe, R. C. Capps, J. J. Whitmore, and Q. R. Murphy. The effect of hexamethonium upon cerebral blood flow and metabolism in patients with premalignant and malignant hypertension. Circulation 1955, 11, 106.

16. Rowe, G. G., G. M. Maxwell, C. A. Castillo, D. J. Freeman, and C. W. Crumpton. A study in man of cerebral blood flow and cerebral glucose, lactate and pyruvate metabolism before and after eating. J. clin. Invest. 1959, 38, 2154.

17. Gupta, T. C., and C. J. Wiggers. Basic hemodynamic changes produced by aortic coarctation of different degrees. Circulation 1951, 3, 17.

18. Wright, J. L., H. B. Burchell, E. H. Wood, E. A. Hines, Jr., and O. T. Clagett. Hemodynamic and clinical appraisal of coarctation four to seven years after resection and end-to-end anastomosis of the aorta. Circulation 1956, 14, 806.

19. March, H. W., H. N. Hultgren, and F. Gerbode. Immediate and remote effects of resection on the hypertension in coarctation of the aorta. Brit. Heart J. 1960, 22, 361.

20. Lambertsen, C. J., R. H. Kough, D. Y. Cooper, G. L. Emmel, H. H. Loeschcke, and C. F. Schmidt. Oxygen toxicity. Effects in man of oxygen inhalation at 1 and 3.5 atmospheres upon blood gas transport, cerebral circulation, and cerebral metabolism. J. appl. Physiol. 1953, 5, 471.

21. Kety, S. S., and C. F. Schmidt. The effects of altered arterial tensions of carbon dioxide and oxygen on cerebral blood flow and cerebral oxygen consumption of normal young men. J. clin. Invest. 1948, 27, 484. 